\title{
The Effect of Financial Risk Management on the Financial Performance of Commercial Banks in Kenya
}

\author{
Stephen Muthii Wanjohi ${ }^{1}$, Joel Githinji Wanjohi ${ }^{2}$, James Muchiri Ndambiri ${ }^{3}$ \\ ${ }^{1}$ Department of Statistics and Actuarial Science, Jomo Kenyatta University of Agriculture and Technology, Nairobi, Kenya \\ ${ }^{2}$ Department of Humanities, University of Nairobi, Nairobi, Kenya \\ ${ }^{3}$ Department of Humanities, Chuka University, Chuka, Kenya
}

Email address:

Wanjohi8280@yahoo.com (S. M. Wanjohi), Joelgithinji7@gmail.com (J. G. Wanjohi), james@jamesndambiri.me.ke (J. M. Ndambiri)

\section{To cite this article:}

Stephen Muthii Wanjohi, Joel Githinji Wanjohi, James Muchiri Ndambiri. The Effect of Financial Risk Management on the Financial Performance of Commercial Banks in Kenya. International Journal of Finance and Banking Research. Vol. 3, No. 5, 2017 , pp. 70-81. doi: $10.11648 /$ j.jifbr.20170305.12

Received: April 19, 2017; Accepted: June 16, 2017; Published: November 23, 2017

\begin{abstract}
An efficient risk management system is the need of time. Managing risk is one of the basic tasks to be done, once it has been identified and known. The risk and return are directly related to each other, which means that increasing one will subsequently increase the other and vice versa. The purpose of this study was to analyze the effect of financial risk management on the financial performance of commercial banks in Kenya. In achieving this objective, the study assessed the current risk management practices of the commercial banks and linked them with the banks' financial performance. Return on Assets (ROA) was averaged for five years (2008-2012) to proxy the banks' financial performance. To assess the financial risk management practices, a self- administered survey questionnaire was used across the banks. The study used multiple regression analysis in the analysis of data and the findings were presented in the form of tables and regression equations. The study found out that majority of the Kenyan banks were practicing good financial risk management and as a result the financial risk management practices mentioned herein have a positive correlation to the financial performance of commercial banks in Kenya. Although there was a general understanding about risk and its management among the banks, the study recommends that banks should devise modern risk measurement techniques such as value at risk, simulation techniques and Risk-Adjusted Return on Capital. The study also recommendsuseofderivativestomitigatefinancialriskaswellasdevelop training courses tailored to the needs of banking personnel in risk management.
\end{abstract}

Keywords: Financial Performance, Risk Management, Financial Risk

\section{Introduction}

\subsection{Background to the Study}

The term financial risk may be used like an umbrella term for multiple types of risk associated with financing, including financial transactions that include company loans in risk of default. [4]Say that financial risk arises from possible losses in financial markets due to movements in financial variables. It is usually associated with leverage with the risk that obligations and liabilities cannot be met with current assets. Our focus in this study will use the term financial risks to broadly cover credit risk, market (price) risk, interest rate risk, liquidity risk and foreign exchange risk. Financial risk may be caused by variation in interest rates, currency exchange rates, variation in market prices, default risk and liquidity gap that affect the cash flows and, therefore its financial performance and competitive position in product markets. Indeed most of the Kenyan Commercial banks outline credit risk, liquidity risk, market risk, interest rate risk and foreign exchange risk as the most important types of financial risks they face.

Financial Risk management can therefore be defined as a set of financial activities that maximizes the performance of a bank by reducing costs associated with the cash flow volatility. The manager's behavior toward risk (risk appetite and risk aversion) and corporate governance can affect the choice of risk management activities. [59] Notes that a robust risk management framework can help banks to reduce their exposure to risks, and enhance their ability to compete in the 
market. Today, banks financial risk management is one of the most important key functions in banking operations as commercial banks are in the risk business. Al-[4] Notes that in today's dynamic environment, all banks are exposed to a large number of risks such as credit risk, liquidity risk, foreign exchange risk, market risk and interest rate risk, among others - the risks which may create some source of threat for a bank's survival and success.

[19] Notes that the crisis that affected global financial stability and the economy in 2007-09 has reinforced the need to rethink some of the approaches adopted by the financial community in assessing bank performance. To this end, it is important to obtain a comprehensive view of the key factors that may influence banks' performance, including the adequacy of business models in relation to risk appetite, and the question of how this adequacy is handled inside and outside banks through governance processes. Against this backdrop, appropriate benchmarks, sensitivity analyses as well as stress tests ought to be considered in order to assess the real capability of banks to face stressed market conditions and absorb consecutive shocks on the basis of their business strategy and degree of risk tolerance.

\subsubsection{Financial Risk Management}

BCBS (2001) defines financial risk management as a sequence of four (4) processes: (1) the identification of events into one or more broad categories of market, credit, operational and other risks into specific sub-categories; (2) the assessment of risks using data and risk model; (3) the monitoring and reporting of the risk assessments on a timely basis; and (4) the control of these risks by senior management. Because of the vast diversity in risk that banking institutions take, there is no single risk management guidelines for banking institutions prescribed risk management system that works for all. Each banking institution should tailor its risk management program to its needs and circumstances. However, given the critical role of banks for a modern market economy, the opacity of banks' balance sheets, the dispersion of banks' creditors - typically many small depositors - and the maturity transformation banks perform converting short-term deposits into mediumto long-term assets there is need for regulations in the banks.

Once risks have been identified, they should be measured in order to determine their impact on the banking institution's profitability and capital. This can be done using various techniques ranging from simple to sophisticated models. Accurate and timely measurement of risk is essential to effective risk management systems. An institution that does not have a risk measurement system has limited ability to control or monitor risk levels. Banking institutions should periodically test their risk measurement tools to make sure they are accurate. Good risk measurement systems assess the risks of both individual transactions and portfolios. After measuring risk, an institution should establish and communicate risk limits through policies, standards, and procedures that define responsibility and authority. These limits should serve as a means to control exposure to various risks associated with the banking institution's activities.

Financial risk management has become a booming industry starting ' 90 as a result of the increasing volatility of financial markets, financial innovations (financial derivatives), the growing role played by the financial products in the process of financial intermediation, and important financial losses suffered by the companies without risk management systems (for example, Enron and WorldCom), [43]. [76] Also notes that Risk Management as commonly perceived does not mean to minimize risk; in fact, its goal is to optimize the risk-reward trade off. And, the role of risk management is to assure that an institution does not have any need to engage in a business that unnecessarily imposes risk upon it. [81] Notes that risk management is still evolving in Kenya and therefore many institutions lack adequate information on effective risk management methodologies.

\subsubsection{Financial Performance}

Financial performance is the measuring of bank's policy and operations in monetary form. It also shows a bank's overall financial health over a period of time, and it helps to compare different banks across the banking industry at the same time. In his study

[84] Defined financial performance as a general measure of how well a bank generates revenues from its capital. [80] Looked at financial performance as a subjective measure of how well a firm uses it assets from primary mode of business to generate revenue. In order to assess the financial performance of commercial banks there are variety of indicators which may be used. Some of the major financial performance indicators include Return on Asset (ROA), Return on Equity (ROE), profitability and Risk-Adjusted Return on Capital (RAROC).

Return on Equity (ROE) is an internal performance measure of shareholder value, and it is by far the most popular measure of performance. ROE proposes a direct assessment of the financial return of a shareholder's investment. It is easily available for analysts, only relying upon public information; and it allows for comparison between different companies or different sectors of the economy.

$\mathrm{ROE}=$ net income / average total equity

ROE is sometimes decomposed into separate drivers known as the DuPont analysis, Where:

$\mathrm{ROE}=($ result $/$ turnover $) *($ turnover/total assets $) *($ total assets/equity).

The first element is the net profit margin, the second element represents the efficiency of the assets and the last corresponds to the financial leverage multiplier. ROE reflects how effectively a bank management is using shareholders' funds. Thus, it can be deduced from the above statement that the better the ROE the more effective the management in utilizing the shareholders capital.

The Return on Assets (ROA) is the net income for the year divided by total assets, usually the average value over the year. ROA measures the ability of the bank management to 
generate income by utilizing company assets at their disposal. In other words, it shows how efficiently the resources of the company are used to generate the income. [53]Says that ROA indicates the efficiency of the management of a company in generating net income from all the resources of the institution.

Risk-Adjusted Return on Capital (RAROC) allows banks to allocate capital to individual business units according to their individual business risk. As a performance evaluation tool, it then assigns capital to business units based on their anticipated economic value added. RAROC is the key measures of bank profitability. The theoretical RAROC can be extracted from the one-factor CAPM as the excess return on the market per unit of market risk (the market price of risk). This measure takes into account the bank's cost of capital. RAROC adjusts the value-added in relation to the capital needed. However, literature is quite critical of this measure as a tool to analyze performance, essentially due to its thorough accounting basis, while it is then difficult to calculate RAROC without having access to internal data. Furthermore, it appears that RAROC may be appropriate for activities with robust techniques for measuring statistical risk, such as credit activity.

\subsubsection{Effects of Financial Risk Management on Financial Performance}

Efficient financial risk management is required in any organization as return and risk are directly related to each other meaning that increase in one will subsequently increase the other and vice versa.[40]Notes that effective risk management leads to more balanced trade-off between risk and reward, to realize a better position in the future.[76]Notes that the banking industry recognizes that an institution needs not do business in a manner that unnecessarily imposes risk upon it; nor should it absorb risk that can be efficiently transferred to other participants. Rather, it should only manage risks at the firm level that are more efficiently managed there than by the market itself or by their owners in their own portfolios. In short, it should accept only those risks that are uniquely a part of the bank's array of services.

Financial risk caused by variation in interest rates, currency exchange rates; default and poor liquidity management may have negative effects on the bottom-line of the bank. [8] Notes that bank risk taking has some effects on bank profits (Performance) as indicated by total assets, total deposit, net interest, margin and net income. Also [26] Notes that the profitability of a bank depends on its ability to foresee monitor and avoid risks, and possibility of provisions to cover losses brought about by risk that arises [29] Notes that the ultimate objective of risk management implementation is to maintain financial performance in the banking sector as aspects of financial risk management promote early warning system of monitoring relevant indicators; as well as stimulating and making provisions for possible realistic strains on the system by conducting stress testing.

\subsubsection{Commercial Banks in Kenya}

Commercial banks are financial intermediary institutions that take deposits and gives credit amongst other financial services. In Kenya, the banking sector plays a dominant role in the financial sector, particularly with respect to mobilization of savings and provision of credit. As per Bank Supervision Annual Report (2012) the banking sector consisted of the Central Bank of Kenya, as the regulatory authority, 44 banking institutions (43 commercial banks and 1 mortgage finance company -MFC). Out of the 44 banking institutions, 31 locally owned banks comprise 3 with public shareholding and 28 privately owned while 13 are foreign owned. The foreign owned financial institutions comprise of 9 locally incorporated foreign banks and 4 branches of foreign incorporated banks. During the period 2008-2012, the Kenyan banking system showed resilience, which was attributed in part to the low financial integration in the global financial market and the intensive supervision and sound regulatory reforms [30].

\subsection{Research Problem}

Commercial banks adopt different risk management practices majorly determined by; ownership of the banks (privately owned, foreign owned, publicly owned), risk policies of banks, banks regulatory environment and the caliber of management of the banks. It's important to study how banks are managing the broader financial risk.

[68] In study for impact of credit risk management on financial performance of commercial banks in Kenya found that there was strong impact between CAMEL components on financial performance. The study mainly focused on one element of financial risk-credit risk. However there is little study that has been done in Kenya to establish how the broader financial risk management affects the financial performance of commercial banks in Kenya.

\subsection{Research Objective}

To establish the effect of financial risk management on the financial performance of the commercial banks in Kenya.

\subsection{Value of the Study}

The study will contribute to the evolution of the important subject of financial risk management. Specifically, the study will explain the extent to which theoretical risk models such Value at Risk (VAR) are used by banks to measure the risks.

The study will provide insight in the most successful strategies banks use to handle financial risk. The findings of the study will assist Central Bank of Kenya in formulating guidelines that will enhance financial risk management in the banking sector. The study will also be important to the commercial banks that will be able to understand the risk management practices that contribute to financial performance of commercial banks and ensure that they undertake acceptable banking practices and procedures.

Academicians will benefit from the information of the study as the study will contribute to existing body of 
knowledge. The study will further provide the background information to research organizations and scholars and identify gaps in the current research for further research.

\section{Literature Review}

\subsection{Modern Portfolio Theory (MPT)}

Modern portfolio theory (MPT) is a theory of finance that attempts to maximize portfolio expected return for a given amount of portfolio risk, or equivalently minimize risk for a given level of expected return, by carefully choosing the proportions of various assets. Prior to Markowitz's work, "Portfolio Selection," published in 1952 by the Journal of Finance, investors focused on assessing the risks and rewards of individual securities in constructing their portfolios intuitively. Markowitz formalized this intuition. Detailing mathematics of diversification, he proposed that investors focus on selecting portfolios based on those portfolios' overall risk-reward characteristics instead of merely compiling portfolios from securities that each individually has attractive risk-reward characteristics. This means that investors should select portfolios not individual securities. Treating Single-period returns for various securities as random variables, this could be done by assigning them expected values, standard deviations and correlations. Based on these, we can calculate the expected return and volatility of any portfolio constructed with those securities. We may treat volatility and expected return as proxies for risk and reward. Out of the entire universe of possible portfolios, certain ones will optimally balance risk and reward. These comprise what Markowitz called an efficient frontier of portfolios. An investor should select a portfolio that lies on the efficient frontier.

[83] Expanded on Markowitz's work by adding a risk-free asset to the analysis. This made it possible to leverage or deleverage portfolios on the efficient frontier. This led to the notions of a super-efficient portfolio and the capital market line. Through leverage, portfolios on the capital market line are able to outperform portfolio on the efficient frontier. [77] Formalized the capital asset pricing model (CAPM).

\subsection{Moral Hazard Theory}

A moral hazard is where one party is responsible for the interests of another, but has an incentive to put his or her own interests first. For example one might take risks that someone else will have to bear. Moral hazards such as these are a pervasive and inevitable feature of the financial system and of the economy more generally. [56] Described moral hazard as "any situation in which one person makes the decision about how much risk to take, while someone else bears the cost if things go badly."

[85] Aptly put it, no other industry but finance "has a comparable talent for privatizing gains and socializing losses. Instead of "creating value," as we were repeatedly assured, the practices of financial engineering (including structured finance and alternative risk transfer), huge leverage, aggressive accounting and dodgy credit rating have enabled their practitioners to extract value on a massive scale-to walk away with the loot, not to put too fine a point on itwhile being unconstrained by risk management, corporate governance, and financial regulation, all of which have proven to be virtually useless'.

\subsection{Merton's Default Risk Model}

The quantitative modeling of credit risk initiated by [61], Shows how the probability of company default can be inferred from the market valuation of companies. The original Merton model was based on some simplifying assumptions about the structure of the typical firm's finances. The event of default was determined by the market value of the firm's assets in conjunction with the liability structure of the firm. When the value of the assets falls below a certain threshold (the default point), the firm is considered to be in default. A critical assumption is that the event of default can only take place at the maturity of the debt when the repayment is due. Many theoretical studies suggested models that relax some of the restrictive assumptions in the Merton model. However, empirical literature mainly focused on the application of the original model.

\subsection{Determinants of Banks Financial Performance}

The financial performance of commercial banks can be determined by either internal factors or external factors. Internal factors could be bank specific determinants while external factors are Industry specific determinants and Macroeconomic determinants. Bank specific indicators include: growth in bank assets, capital adequacy, operational efficiency, and liquidity. Industry specific factors include: ownership, bank size, bank concentration index. While on the other hand, the key macroeconomic variables include: growth in GDP, GDP-percapita, inflation expectation, interest rate and its spread.

[71]Using data for the 14 largest banks in China for the period 1993-2003, studies the determinants of commercial bank performance in China. The study concluded that, performance of commercial banks in China was mainly determined by firm-level factors such as cost management capability and risk management capability. The study on Malaysian banks by [44] also shows that efficient management is among the most important factors that explain high bank profitability. [78] Found a positive and significant relationship between size and bank profitability.

[3] Provided evidence of the importance of macroeconomic factors in determining the profitability of banks [69] Concluded that the financial performance of commercial banks in Kenya was driven mainly by board and management decisions, while macroeconomic factors had insignificant contribution.

\subsection{Empirical Literature Review}

[4] Provided a comparative study of Bank's Risk Management of UAE National and Foreign Banks. This research helped them to find that the three most important 
types of risks facing the UAE commercial banks were foreign exchange risk, followed by credit risk and then operating risk. They found that the UAE banks were somewhat efficient in managing risk; however the variables such as risk identification, assessment and analysis proved to be more influencing in risk management process. Finally, the results indicated that there was a significant difference between the UAE National and Foreign banks in practicing risk assessment and analysis, and in risk monitoring and controlling.

[45], made a study "Risk Management Practices of Islamic Banks of Brunei Darussalam" to assess the degree to which the Islamic banks in Brunei Darussalam implemented risk management practices and carried them out thoroughly by using different techniques to deal with various kinds of risks. The results of the study showed that, like the conventional banking system, Islamic banking was also subjected to a variety of risks due to the unique range of offered products in addition to conventional products. The results showed that there was a remarkable understanding of risk and risk management by the staff working in the Islamic Banks of Brunei Darussalam, which showed their ability to pave their way towards successful risk management.

[49] In their study on credit risk management and profitability in commercial banks in Sweden highlighted that credit risk management has effect on profitability. The analysis further indicated that the impact of the credit risk management on profitability for the 4 commercial banks sampled was not the same. The study was limited to identifying the relationship of credit risk management and profitability banks in Sweden.

[54], did a study "Credit Risk Management and Profitability of Commercial Banks in Kenya", to assess the degree to which the credit risk management in practice had significantly contributed to high profits in commercial banks of Kenya. Data on the amount of credit, level of nonperforming loans and profits were collected for the period2004 to 2008. The results of the study showed that, there was no relationship between profits, amount of credit and the level of nonperforming loans. The findings reveal that the bulk of the profits of commercial banks were not influenced by the amount of credit and nonperforming loans suggesting that other variables other than credit and nonperforming loans impact on profits.

[38] Investigated on whether a strong and independent risk management is significantly related to bank risk taking and performance during the credit crisis in a sample of 74 large bank holding companies. They constructed a risk management index (RMI) which was based on five variables relating to the strength of banks risk management: dummy variable whether the bank has a designated CRO who is member of the executive board, a dummy variable whether the CRO is among the top five highly paid executives, the ratio of the CRO's total compensation to the Chief Executive Officer's total compensation, a dummy variable whether at least one of the non-executive directors of the bank's risk committee has banking experience, and a dummy variable whether the bank's risk committee met more frequently in the respective year as compared to the average value across the other sample banks. Their findings indicated that banks with high RMI value in 2006 had lower exposure to private-label mortgage-backed securities, were less active in trading offbalance sheet derivatives and had a smaller fraction of nonperforming loans, a lower downside risk and a higher Sharpe Ratio during the crisis years 2007-2008.

[2] On his study" Assessing and the Risk Performance of the GCC Banking" assessed the impact of bank's specific risk characteristics, and the overall banking environment on the performance of 43 commercial banks operating in 6 of the Gulf Cooperation Council (GCC) countries over the period 1998-2008. Using fixed effect regression analysis, results showed that credit risk, liquidity risk and capital risk are the major factors that affect bank performance when profitability is measured by return on assets while the only risk that affects profitability when measured by return on equity is liquidity risk.

[73] On his paper "Do Effective Risk Management Affect Organizational Performance" assesses the current practices of risk management in Pakistani software development sector. Based on the data, collected from 25 organizations working in software development sector, the results indicated that risk management practices were not widely used by the organization(s); moreover most of the organizations did not have documented risk management policy properly. Therefore, these organizations could not deal with the risks systematically and sometimes faced negative consequences for the non-systematic approaches. However, few companies had implemented certain risk management techniques and are enjoying high performance.

[5] Did a study on "The Influence of Financial Risk Management on The Financial Performance of Commercial Banks in Kenya". The study sought to assess the influence of financial risk management practices namely; Risk aggregation and Capital Allocation practices, Supervision and Regulation, Disclosures and Funded and Unfunded Credit protection on the Financial Performance on Commercial Banks in Kenya. The specific objectives were to determine the influence that these practices have had on the financial performance of commercial banks in Kenya and to establish the relationship between Financial Risk Management and Financial Bank performance. The study used a descriptive survey of commercial banks in Kenya. The credit and management staff of the forty two commercial banks and one mortgage company formed the target population with a sample size of one hundred and seven staff randomly chosen for the study. Primary data through close ended questions was collected in this study on the financial risk management practices employed and their influence on the financial performance of the commercial banks. Data was analyzed using correlation analysis and regression models with the strength of the model being tested using Cornbrash's Co-efficient Alpha. The study found that most commercial banks had highly adopted financial risk management practices to manage financial and credit risk and as a result the financial risk management practices mentioned herein 
have a positive correlation to the financial performance of commercial banks of Kenya. The study recommended that commercial banks should seek and obtain information consistently so as to permit them to detect potential problems at an early stage and identify trends not only for particular institutions, but also for the banking system as a whole, while also ensuring transparency of banking activities and the risks inherent in those activities, including credit risk.

[55] On his study "Credit Risk And Commercial Banks' Performance In Nigeria: A Panel Model Approach." carried out an empirical investigation into the quantitative effect of credit risk on the performance of commercial banks in Nigeria over the period of 11 years (2000 - 2010). Five Commercial banking firms were selected on a cross sectional basis for eleven years. The traditional profit theory was employed to formulate profit, measured by Return on Asset (ROA), as a function of the ratio of Non - performing loan to loan \& Advances (NPL/LA), ratio of Total loan \& Advances to Total deposit (LA/TD) and the ratio of loan loss provision to classified loans (LLP/CL) as measures of credit risk. Panel model analysis was used to estimate the determinants of the profit function. The results showed that the effect of credit risk on bank performance measured by the Return on Assets of banks is cross - sectional invariant. That is the effect is similar across banks in Nigeria, though the degree to which individual banks are affected is not captured by the method of analysis employed in the study. A 100 percent increase in non - performing loan reduces profitability (ROA) by about 6.2 percent, a 100 percent increase in loan loss provision also reduces profitability by about 0.65 percent while a 100 percent increase in total loan and advances increase profitability by about 9.6 percent. Based on the study findings, the study recommended that banks in Nigeria should enhance their capacity in credit analysis and loan administration while the regulatory authority should pay more attention to banks' compliance to relevant provisions of the Bank and other Financial Institutions Act (1999) and prudential guidelines.

[67] Provided a comparative study of Credit Risk Management on Financial Performance of Commercial Banks in Kenya. A causal research design was undertaken in this study and this was facilitated by the use of secondary data which was obtained from the Central Bank of Kenya publications on banking sector survey. The study used multiple regression analysis in the analysis of data and the findings were presented in the form of tables and regression equations. The study found out that there was a strong impact between the CAMEL components on the financial performance of commercial banks. The study also established that capital adequacy, asset quality, management efficiency and liquidity (CAMEL) had weak relationship with financial performance (ROE) whereas earnings had a strong relationship with financial performance. The study concluded that CAMEL model can be used as a proxy for credit risk management.

[69] On their study "Determinants of Financial Performance of Commercial Banks in Kenya" assessed on moderating effect of ownership structure on bank performance. To fill this glaring gap in this vital area of study, the authors used linear multiple regression model and Generalized Least Square on panel data to estimate the parameters. The findings showed that bank specific factors significantly affect the performance of commercial banks in Kenya, except for liquidity variable. But the overall effect of macroeconomic variables was inconclusive at 5\% significance level. The moderating role of ownership identity on the financial performance of commercial banks was insignificant. Thus, they concluded that the financial performance of commercial banks in Kenya was driven mainly by board and management decisions, while macroeconomic factors have insignificant contribution.

\section{Research Methodology}

\subsection{Research Design}

The research used a descriptive research design. Descriptive survey research portrays an accurate profile of persons, events, or account of the characteristics, for example behavior, opinions, abilities, beliefs, and knowledge of a particular individual, situation or group [26]. The descriptive survey method was preferred because it would ensure complete description of the situation (in depth study of financial risk management), making sure that there was minimum bias in the collection of data.

\subsection{Population}

The target population comprised of the forty three (43) commercial banks and one Mortgage Company making it 44 Banks.

\subsection{Data Collection}

The study used both primary data and secondary data

The primary data for this study was collected using personally administered questionnaires. The questionnaire was adapted from [52] and [6]. The questionnaire consisted of six sections. The first section was designed to gather the institutional information. The second section was designed to gather information about the risk management environment. The other sections gathered information about risk measurement followed by risk monitoring, risk mitigation and internal control techniques adopted by the commercial banks. The questionnaire was designed to consist of 5 likert scale point, 5 for strongly agree, 4 for agree, 3 for no opinion, 2 for disagree and 1 for strongly disagree. The secondary data was collected from the various CBK Bank Supervision Annual Reports. The five years (2008-2012) annual ROAratiowas averaged to form the dependent variable (financial performance).

\subsection{Data Analysis}

Inferential statistics was used to examine the casual relationships between the financial risk management and the banks financial performance. An F-test was used to assess 
how well the set of independent variables, as a group, explains the variation in the dependent variable/ effectiveness of the model as a whole in explaining the dependent variable. We used a t-test to assess the significance of the individual regression parameters/assessing whether the individual coefficients were statistically significant

\subsubsection{Model Specification}

The study utilized the regression analysis with the equation of the form. The model provided a statistical technique for estimating the relationship between the financial risk management and the financial performance of the banks.

$$
\mathrm{Y}=\alpha+\mathrm{b}_{1} \mathrm{X}_{1}+\mathrm{b}_{2} \mathrm{X}_{2}+\mathrm{b}_{3} \mathrm{X}_{3}+\mathrm{b}_{4} \mathrm{X}_{4}+\mathrm{b}_{5} \mathrm{X}_{5}+\varepsilon
$$

Where:

$\alpha=$ constant/the interception point of the regression line and the $y$-axis

$b_{1}, b_{2} \ldots b_{5}$ are the coefficients of the independent variables that will be determined. $\mathrm{Y}=$ Financial performance measured by the simple average ROA (2008-2012)

$\mathrm{X}_{1}=$ Risk Management Environment. $\mathrm{X}_{2}=$ Risk Measurement.

$\mathrm{X}_{3}=$ Risk Mitigation. $\mathrm{X}_{4}=$ Risk Monitoring.

$\mathrm{X}_{5}=$ Adequate Internal Control.

$\varepsilon=$ disturbance term or error term

The independent variables $\mathrm{X} 1, \mathrm{X} 2 \ldots \ldots \mathrm{X} 5$ were operationalized and measured using the questions posted in the questionnaire.

\subsubsection{Operationalization of the Study Variables}

To measure the financial risk management practices, five important components in reference to Basel Committee on Banking Supervision (1999 and 2001b) were used to formulate the questionnaire. The five components were Risk Management Environment, Risk Measurement, Risk Mitigation, Risk Monitoring and Adequate Internal Control. All these five components were then linked with the mean of ROA for the five years (2008-2012).

The variables were measured as follows:

Table 1. Operationalization of the Study Variables.

\begin{tabular}{|c|c|}
\hline Variable & Measurement \\
\hline ROA & $\begin{array}{l}\text { ReturnonAssetwasmeasuredastheratioofnetincometo. Averagetotal assets for the respective bank. Asimpleaverage. ROA for the five } \\
\text { years (2008-2012) was used. }\end{array}$ \\
\hline $\begin{array}{l}\text { Risk Management } \\
\text { Environment. }\end{array}$ & $\begin{array}{l}\text { To come up with the quantitative assessment of Risk Management. Environment the quantification points were assigned (using likert } \\
\text { scale) for the different questions in the section and adding them up to get the total numerical score of } 100 \% \text {. The resulting index gave } \\
\text { an indication of the overall status of risk management in the bank. }\end{array}$ \\
\hline Risk Measurement & $\begin{array}{l}\text { The quantitative assessments of Risk Measurement points wereassigned(usinglikertscale)forthedifferentquestionsinthe section and } \\
\text { adding them up to get the total numerical score of } 100 \% \text {. The resulting index gave an indication of the overall status of risk } \\
\text { management in the bank. }\end{array}$ \\
\hline RiskMitigation & $\begin{array}{l}\text { The quantitative assessment of Risk Mitigation the quantification } \\
\text { Points were assigned (using likert scale) for the different questions in the section and adding them up to get the total numerical score } \\
\text { of } 100 \% \text {. The resulting index gave an indication of the overall status of risk management in the bank. }\end{array}$ \\
\hline & The quantitative assessment of Risk Monitoring the quantification \\
\hline Risk Monitoring & $\begin{array}{l}\text { Points were assigned (using likert scale) for the different questions in the section and adding them up to get the total numerical score } \\
\text { of } 100 \% \text {. The resulting index gave an indication of the overall status of risk management in the bank. }\end{array}$ \\
\hline $\begin{array}{l}\text { AdequateInternal } \\
\text { Control }\end{array}$ & $\begin{array}{l}\text { ThequantitativeassessmentofAdequateInternalControltheQuantification points were assigned (using likert scale) for the different } \\
\text { questions in the section and adding them up to get the total numerical score of } 100 \% \text {. The resulting index gave an indication of the } \\
\text { overall status of risk management in the bank. }\end{array}$ \\
\hline
\end{tabular}

\section{Data Analysis, Results and Discussion}

\subsection{Financial Risk Management Practices in Kenyan Banks}

To assess the level of financial risk management practices in the Kenyan commercial banks by using the descriptive tests, the study used the 5-Likert scale approach in the questionnaire. The higher the scale indicated that the respondent strongly agreed to such practices adopted by their banks. Financial risk management practices were covered in five parts: Risk Management Environment, Risk Measurement Practices, Risk Mitigation Practices, Risk Monitoring Practices and Internal Control Practices as suggested by the [15].

\subsection{Risk Management Environment}

With regard to "Risk Management Environment", the results showed that all the respondents agree with almost all item statements. Majority of the respondents (with a mean of over 4.5) strongly agreed with seven items, namely item: There is a formal system of Risk Management in the bank; item: The Board of directors outlines the overall risk objectives; item: There is a section/department responsible for identifying, monitoring, and controlling various risks; item: The bank have internal guidelines/rules and concrete procedures with respect to the risk management system; item: The bank has the policy of diversifying investment across different sectors ;item: Your Bank has adopted and utilized Revised CBK Financial Risk management Guidelines; and item: Your Bank has adopted and utilized Revised CBK Prudential Guidelines.

\subsection{Risk Measurement}

Moving on to the risk measurement practices, only three items statement scored a mean of 4 , that is the respondents agreed on the items statement. The item statements were; the 
bank regularly conducts simulation analysis and measure benchmark (interest) rate risk sensitivity; the bank uses Maturity Matching Analysis and item statement; the bank uses Estimates of Worst Case scenarios/stress testing for risk analysis. This is an indication that the risk measurements techniques are still developing in the Kenyan banks.

Value at Risk analysis, Risk Adjusted Rate of Return on Capital (RAROC) were not common measurements of risk in the Kenyan Banks as they scored a mean of 2 which showed that majority of the respondents were not aware of the techniques. Majority of the banks also confirmed that there were no internal risk rating systems as well as computerized support system for estimating the variability of earnings and risk management. These areas may need improvement in order to assist the bank in managing the risks efficiently.

\subsection{Risk Mitigation}

For risk mitigation practices, majority of item statements scored a mean 3.5-4.3 which are considered good. However, item; "there are derivatives instruments to mitigate financial risk" scored a mean of 1.4 meaning majority of the respondents did not agree that Kenyan banks use derivative instruments to mitigate financial risk. This area may need improvement in order to assist the banks in managing the risks efficiently.

\subsection{Risk Monitoring}

On the frequency of generating risk reports indicate that majority of the banks generates monthly risk reports. This can as well be classified as good risk management technique.

Moving on to the risk monitoring practices all the items statement scored a mean of 3.5-4.6. This is a good indication of risk management.

\subsection{Adequate Internal Control}

For internal control practices, the respondents strongly agreed in all items. This can be considered as good practice.

Overall, for the Kenyan banks the best financial risk management practice is for Adequate Internal Controls Practice which obtained the highest mean of 90 per cent, followed by Risk Management Environment Practices (mean of 88 per cent). The Risk Monitoring Practice showed a mean of 73 per cent while Risk Mitigation practices recorded a mean of 72 per cent. The Risk Measurement practices recorded the lowest mean of 60 per cent.

\subsection{Financial Performance of the Commercial Banks in Kenya}

2008-2012

Average returns on assets (ROA) for the Kenyan banks in 2008 was 2.03 per cent, 2009 was 1.65 per cent, 2010 was 2.93 per cent, 2011 was 2.88 per cent and 2012 was 2.49 per cent. Thus on average the return on assets of the banking industry decreased during the period

2010-2012. Notably Jamii Bora Bank Limited was converted into a bank in 2010 while UBA Kenya Bank Limited started its operations on 2009. Charterhouse Bank Limited was excluded from the survey as it's under statutory management. The average figures for each year take into account the number of institutions that were in operation in each of the years.

\subsection{Regression Model}

The regression equation was of the form:

$$
\mathrm{Y}=\alpha+\mathrm{b}_{1} \mathrm{X}_{1}+\mathrm{b}_{2} \mathrm{X}_{2}+\mathrm{b}_{3} \mathrm{X}_{3}+\mathrm{b}_{4} \mathrm{X}_{4}+\mathrm{b}_{5} \mathrm{X}_{5}+\varepsilon
$$

Where:

$\alpha=$ constant/the interception point of the regression line and the $y$-axis

$b_{1}, b_{2} \ldots . b_{5}$ are the coefficients of the independent variables that will be determined.

$\mathrm{Y}=$ Financial performance measured by the simple average ROA (2008-2012) $\mathrm{X}_{1}=$ Risk Management Environment.

$\mathrm{X}_{2}=$ Risk Measurement.

$\mathrm{X}_{3}=$ Risk Mitigation. $\mathrm{X}_{4}=$ Risk Monitoring.

$\mathrm{X}_{5}=$ Adequate Internal Control.

$\varepsilon=$ disturbance term or error term

The regression model arising from the data in the table 2 below is of the form; $\mathrm{Y}=0.059 \mathrm{X}_{1}+$ $0.095 \mathrm{X}_{2}+0.079 \mathrm{X}_{3}+0.046 \mathrm{X}_{4}+0.091 \mathrm{X}_{5}-0.252$

Table 2. Regression Coefficients.

\begin{tabular}{|c|c|c|c|c|c|}
\hline \multirow{2}{*}{ Model } & \multicolumn{2}{|c|}{ UnstandardizedCoefficients } & \multirow{2}{*}{$\begin{array}{l}\text { StandardizedCoefficients } \\
\text { Beta }\end{array}$} & \multirow{2}{*}{$\mathbf{t}$} & \multirow{2}{*}{ Sig. } \\
\hline & $\mathbf{B}$ & Std. Error & & & \\
\hline 1 (Constant) & -0.252 & 0.023 & & -10.858 & 0 \\
\hline Risk Management Environment & 0.059 & 0.024 & 0.164 & 2.489 & 0.02 \\
\hline Risk Measurement & 0.095 & 0.016 & 0.408 & 5.852 & 0 \\
\hline Risk Mitigation & 0.079 & 0.015 & 0.387 & 5.141 & 0 \\
\hline Risk Monitoring & 0.046 & 0.014 & 0.199 & 3.382 & 0.002 \\
\hline Adequate Internal Controls & 0.091 & 0.024 & 0.234 & 3.812 & 0.001 \\
\hline
\end{tabular}

a. Dependent Variable: Average Return on Asset (2008-2012)

Source; Research Findings

The model means that financial performance is highly dependent on the level of the financial risk management. The t-test indicates that the financial performance is highly dependent of risk measurement practices and risk mitigation practices. 


\subsection{Interpretation of Findings}

The study found that there was a significant relationship between the financial risk management practices on the financial performance of commercial banks. A strong positive correlation between ROA and risk mitigation practices $(+85 \%)$ existed. A strong positive correlation relationship $(+79 \%)$ exists between ROA and risk measurement practices. Moreover, there moderate correlations between ROA and internal control practices, risk management environment and risk monitoring practices (54\%, $47 \%$ and $48 \%$, respectively). Based on these correlations, it can be concluded that the higher the ROA for Kenyan commercial banks, the better will be the risk mitigation practices and also risk measurement practices in the Kenyan banks. The R-Square indicates that an overwhelmingly $92.9 \%$ of the ROA is explained by the financial risk management practices. The adjusted R-Square of 0.916 also confirms the same. This means that there is a strong effect between the financial performance (ROA) and the financial risk management practice. Results show that financial risk management efficiency significantly affects the financial performance of commercial banks in Kenya. Analysis also shows the regression coefficients and it was established that the intercept value was a negative value of 0.252 . Table 2 also reveals that a unit increase in Risk Management Environment index will cause a 0.059 increase in Return on Asset (ROA) and a unit increase in Risk Measurement index will lead to a 0.095 increase in ROA. A unit increase in Risk Mitigation Index will lead to a 0.079 increase in ROA and a unit increase in Risk Monitoring Index will lead to a 0.046 increase in ROA. Likewise a unit change in Adequate Internal Controls Index would cause a 0.091 positive change in ROA.

\section{Summary of Findings, Conclusion and Recommendations}

\subsection{Summary}

This study used primary data and secondary data to examine the effect of financial risk management practices in Kenyan banks on the financial performance of these Kenyan banks using correlation analysis and regression analysis. All the banks in the study practice good risk management with few areas of improvements. This includes the use of computerized support system for estimating the variability of earnings and risk management. The banks should consider complying with the more stringent guidelines of Basel III in additional to the local CBK guidelines on financial risk management. On budget allocation to risk management sections, most banks had no stand-alone budget thus the risk management may not have been fully equipped in terms of resources.

The findings show that Kenyan banks are perceived to use less technically advanced risk measurement techniques of which the most commonly used are credit ratings, gap analysis, duration analysis, maturity matching, estimates of worst case scenarios/stress testing and earnings at risk. The more technically advanced risk measurement techniques which include value at risk, simulation techniques, RAROC and internal-based rating system are perceived not to be used widely by Kenyan banks in the study. On risk mitigation practices it was established that majority of the Kenyan banks had limited use of derivative instruments to mitigate financial risk. These areas may need improvement in order to assist the banks in managing the risks efficiently. Overall the best financial risk management practice is on adequate internal controls practice which obtained the highest mean of 90 per cent followed by risk management environment practices with a mean of 88 per cent. With regard to the type of reports, the reports on credit risk, market risk, interest rate risk, liquidity risk and foreign exchange risk have been produced monthly by the Kenyan banks in the study. Lastly, the study established a very strong relationship between financial risk management practices and financial performance in the Kenyan banks.

\subsection{Conclusions}

The study established that financial risk management had a strong impact on the financial performance of commercial banks in Kenya. The study also established that the risk measurement practice had the biggest impact on financial performance followed by risk mitigation practice. Thus, as each shilling invested in risk measurement techniques and risk mitigation techniques increases revenues generation and the financial performance of banks increases.

\subsection{Recommendation for Policy}

From the finding and basing on the objectives, the study recommends the following; Kenyan banks should expound their risk measurements techniques so as to adequately manage the financial risks resulting from the increased financial innovations in the banking sector. Also the banking institution should explore the use of derivatives to mitigate the financial asset risks. Commercial banks should also check their risk management policy and practices and streamline them with global standards such as the Basel III accords. On budget allocation the banks should ensure risk management sections have a stand-alone budget to ensure resources are availed for the ever changing risk environment.

By this they would efficiently manage the financial risk and consequently increase their financial performance.

\subsection{Areas for Further Research}

The study suggests that a further study can be done on the effects of financial risk management by use of detailed questionnaire on the financial performance of other financial institutions like the micro finance institutions (MFIs) and development financial institutions (DFIs).

Further research may be directed towards the examination of how Kenyan banks have adopted the Basel III recommendations and how such recommendations have affected their financial risk management and the financial performance. 
Lastly, a study may be directed towards causal relationship between bank Capital and profitability for the Kenyan banks.

\section{References}

[1] Alexandru, C., Genu, G., Romanescu, M. L. (2008). The Assessment of Banking Performances- Indicators of Performance in Bank Area. MPRA Paper No.11600.

[2] Al-Khouri, R. (2011). Assessingthe Riskand Performance of the GCC Banking Sector. International Journal of Finance and Economics, ISSN 1450-2887, Iss. 65, 72-8.

[3] Allen, L. and Saunders, A., (2004). Incorporating Systemic Influences into Risk Measurements: A Survey of the Literature. Journal of Financial Services Research, Vol. 26 , pp. 161-191.

[4] Al-Tamimi, H. and Al-Mazrooei M., (2007). Banks' Risk Management: A Comparison Study ofUAE National and Foreign Banks. The Journal of Risk Finance, Vol. 8 No. 4, pp. 394-409.

[5] Anguka W. (2012). The Influence of Financial Risk Management on the Financial Performance of Commercial Banks in Kenya. MBA Unpublished Research Project, University of Nairobi.

[6] Ariffin N. M. \& Kassim S. H (2011). Risk Management Practices and Financial Performance ofIslamic Banks: Malaysians Evidence. Islamic Economics \& Finance Pedia

[7] Ariffin, N. M, Archer, S., \& Karim, R. A., (2009). Risks in Islamic banks: Evidence from empirical research. Journal of Banking Regulation, 10(2), 153-163.

[8] Athanasoglou P., Delis M. and Staikouras C., (2006). Determinants Of Bank Profitability in theSouth Eastern European Region. Munich Personal RePEc Archive.

[9] Athanasoglou, P., Brissimis, S., and Delis, M., (2005). BankSpecific, Industry-Specific andMacroeconomic Determinants of Bank Profitability. Working Paper, No. 25.

[10] Basel Committee on Banking Supervision (1988). International Convergence of Capital Measurement and Capital Standards. Bank for International Settlement.

[11] Basel Committeeon Banking Supervision (1997). Core Principlesfor Effective Banking Supervision. Bank for International Settlement.

[12] Basel Committee on Banking Supervision (1998). Framework for Internal Control Systems inBanking Organizations. Bank for International Settlement.

[13] Basel Committeeon Banking Supervision (1999). Principles for the Management of Credit Risk. Bank for International Settlement. Bank for International Settlement.

[14] Basel Committee on Banking Supervision (1999a). Performance of Models-Based Capital Charges for Market Risk. Bank for International Settlement.

[15] Basel Committee on Banking Supervision (1999b). Credit Risk Disclosure. Bank for InternationalSettlement.

[16] Basel Committee on Banking Supervision (1999c). Principles for the Management of Credit Risk. Bank for International
Settlement.

[17] Basel Committee on Banking Supervision (1999d). Credit Risk Modeling: Current Practices andApplications. Bank for International Settlement.

[18] Basel Committee on Banking Supervision (2000). Sound Practices for Managing Liquidity inBanking Organizations. Bank for International Settlement.

[19] Basel Committee on Banking Supervision (2001). The New Capital Accord. Bank forInternational Settlement.

[20] Basel Committee on Banking Supervision (2001a). Operational Risk. Bank for International Settlement.

[21] Basel Committee onBanking Supervision (2001b). Principles for the Management and Supervision of Interest Rate Risk. Bank for International Settlement.

[22] Basel Committee on Banking Supervision (2001c). Slowdown of the global OTC derivatives market in the second half of 2000. Bank of International Settlements.

[23] Basel Committee on Banking Supervision (2009). Report on Special Purpose Entities. Bank forInternational Settlement.

[24] Basel Committee on Banking Supervision (2010). Basel III: A global regulatory framework for more resilient banks and banking systems. Bank for International Settlement.

[25] Bharath, S., and T. Shumway, (2008). Forecasting Default with the Merton Distance to DefaultModel. Review of Financial Studies 21, 1339-1369.

[26] Bikker J. A and M etzemakers P. A. J (2005). Bank Provisioning Behavior and Procyclicality. Journal of International Financial Markets, Institutions and Money, Elsevier, Vol 15(2), Pages 141-157.

[27] Bobakovia, I. V. (2003). Raising the Profitability of Commercial Banks, BIATEC, UME XI

[28] Campbell, J. Y., Hilscher, J., and J. Szilagyi. (2008). In Search of Distress Risk. Journal of Finance 63, no. 6: 2899-2939.

[29] Central Bank of Kenya, (2008-2012). Bank Supervision Annual Reports. The Central Bank ofKenya.

[30] Central Bank of Kenya, (2012). Prudential Guidelines for Institutions Licensed under theBanking Act. The Central Bank of Kenya.

[31] Central bank of Kenya, (2013). Risk management Guide Lines. The Central Bank of Kenya. Coleman T. S. (2011) A Practical Guide to Risk Management. Research Foundation of CFAInstitute.

[32] Daianu, Daniel \& Lungu, Laurian, (2008). Why Is This Financial Crisis Occurring? How toRespond To It? Journal for Economic Forecasting.

[33] Dembe, Allard E. and Boden, Leslie I. (2000). "Moral Hazard: A Question of Morality?" New Solutions 10(3). 257-279.

[34] Diffu I. (2011). The Relationship between Foreign Exchange Risk and Financial Performance of Airlines in Kenya: A Case Study of Kenya Airways. MBA Unpublished Research Project, University of Nairobi.

[35] Dionne G. (2013). Risk Management: History, Definition and Critique. Cahiers De Recherche1302, CIRPEE. 
[36] Duffie, D., Saita, L., and K. Wang, 2007, "Multi-period corporate default prediction with stochastic covariates". Journal of Financial Economics 83, 635-665

[37] Economic and Social Research Institute (2003): Trend of the Japanese economy and major topics in and after the 1970.

[38] Ellul, A. \& Yerramilli V. (2010). Stronger Risk Controls, Lower Risk: Evidence from US bankHolding Companies. Indiana University.

[39] Ernst \& Young (2012). Progress in Financial Service Risk Management: A survey of major financial Institutions.

[40] Fatemi A. and Fooladi I. (2006). Credit Risk Management: A Survey of Practices. ManagerialFinance, Vol. 32 Iss: 3, pp.227-233.

[41] Federal Deposit Insurance Corporation. (1997). The Savings and Loan Crisis and Its Relationship to Banking. In History of the Eighties, Lessons for the Future: An Examination of the Banking Crises of the 1980s and Early 1990s. Vol 1. Financial Times.

[42] Gertler M. et al (2010). Financial Crises, Bank Risk Exposure and Government Financial Policy, New York University and Princeton

[43] Gheorghe and Sorin G. (2008), "Lessons From The Current Financial Crisis. A Risk ManagementApproach" "Alexandru Ioan Cuza" University of Iaúi. Publishing House, Iaúi.

[44] Guru, B., Staunton, J. And Balalashanmugam, 2002. Determinants of Commercial Bank Profitability in Malaysia. University of Multimedia Working Papers.

[45] Hassan A. (2009). Risk Management Practices of Islamic Banks of Brunei Darussalam. Journal of Risk Finance, Vol. 10 Issue: 1, pp. 23-37.

[46] Hillegeist, S. A., Keating, E. K., Cram, D. P., Lundstedt, K. G., (2004). Assessing the Probability of Bankruptcy. Review of Accounting Studies 9, 5-34.

[47] Honohan, Patrick, and Laeven, (2005). Systemic Financial Crises: Containment and Resolution. Cambridge, U.K.: Cambridge University Press.

[48] Hosna A., Manzura B. and Juanjuan S. (2009). Credit Risk Management and Profitability inCommercial Banks in Sweden. University of Gothenburg.

[49] Jorion, P., and Khoury, S. J., (1996), Financial Risk Management: Domestic and International Dimensions. Cambridge, Massachusetts: Blackwell Publishers.

[50] Kabiru A. M. (2010). The Effects of Risk Management Practices on the Financial Performance of Commercial Banks in Kenya. MBA Unpublished Research Project, University of Nairobi.

[51] Karr J. (2012). Performance Measurement in the Banking Industry - post-crisis trends. Ernest \& Young

[52] Khan, T., and Ahmed, H. (2001). Risk Management: An Analysis of Issues in Islamic Financial Industry. IRTI/IDB Occasional Paper, No. 5.

[53] Khrawish H. (2011). Determinant of commercial banks performance in Jordan. International Journal of Finance and Economics, 81 .
[54] Kithinji A. M. (2010). Credit Risk Management and Profitability of Commercial. Banks in Kenya. School of Business, University of Nairobi.

[55] Kolapo T. F. (2012). Credit Risk and Commercial Banks' Performance In Nigeria: A Panel ModelApproach. Australian Journal of Business and Management Research Vol. 2. No. 02:31-38.

[56] Krugman, P. (2009). The Return of Depression Economics and the Crisis of 2008.

[57] Laeven L, Valencia F. (2008). Systemic banking crises: a new database. IMF WP/08/224. International Monetary Fund..

[58] Maisa B., (2007). How Bank in Palestine Manage Financial Risk? Al-Zaytoonah University, Jordan.

[59] Markowitz H. (1959). Portfolio Selection: Efficient Diversification of Investments. New York. John Wesley.

[60] McNamee D., McNamee T. (1995). The Transformation of Internal Auditing. Managerial Auditing Journal, Vol. 10 Issue: 2, pp. 34-37.

[61] Merton, R. C. 1974. On the Pricing of Corporate Debt: The Risk Structure of Interest Rates. Journal of Finance 29:449 70 .

[62] Meyer, L. (2000). Why Risk Management Is Important for Global Financial Institutions. Risk Management of Financial Institutions United Nations Conference Center Bangkok, Thailand.

[63] Misati R. N. (2010). Financial Innovation and Monetary Policy Transmission inKenya. International. Research Journal of Finance and Economics ISSN 1450-2887 Issue 50.

[64] Moreno, R. \& Pasadilla, G. \& Remolona, E., (1998). Asia's Financial Crisis: Lessons and PolicyResponses. Papers 98-02, Economisch Institut voor het Midden en Kleinbedrijf.

[65] Mutuku N. (2010). The Impact of the Global Financial Crisis on the Kenyan Retirement Benefits Industry. Retirement Benefits Authority.

[66] Nimalathasan B. (2008). A comparative study of financial performance of banking sector in Bangladesh - An application of CAMELS rating / Annals of University of Bucharest, Economic and Administrative Series, Nr. 2 141-152.

[67] Ogilo F. (2012). The Impact of Credit Risk Management on Financial Performance of Commercial Banks in Kenya. DBA Africa Management Review 2012, Vol 3 No 1 pp. 22-37.

[68] Oludhe J. (2011). The Impact of Credit Risk Management on the Financial Performance of Commercial Banks in Kenya. MBA Unpublished Research Project, University of Nairobi.

[69] Ongore V. O and Kusa G. B (2013). Determinants of Financial Performance of Commercial Banks in Kenya. International Journal of Economics and Financial Issues Vol. 3, No. 1, pp 237-252.

[70] Parreñas, J. C (2005), Banks' Risk Management Practices: A Survey Of Four Asian EmergingMarkets. Taiwan Institute Of Economic Research.

[71] Pyle D. H, (1997), Bank Risk Management: Theory.

[72] Reinhart, Carmen M.; Rogoff, Kenneth S. (2009). This Time is Different: Eight Centuries ofFinancial Folly. Princeton University Press. ISBN 978-0-691-14216-6. 
[73] Saleem S. (2011). Do Effective Risk Management Affect Organizational Performance? EuropeanJournal of Business and Management Vol 3, No. 3.

[74] Santomero A. M. (1996). Commercial Bank Risk Management: An Analysis of the. Process, theWharton School University of Pennsylvania.

[75] Senior Supervisors Group (2009), Risk Management Lessons from the Global Banking Crisis of 2008: Financial Stability Board Bank for International Settlements.

[76] Shafiq A. and Nasr M. (2010). Risk Management Practices Followed By the Commercial Banks in Pakistan. International Review of Business Research Papers Vol. 6. No. 2. Pp. 308325 .

[77] Sharpe W. F. (1964). Capital Asset Prices - A Theory of Market Equilibrium under Conditions ofRisk. Journal of Finance 19: 425-42.

[78] Smirlock, M., (1985). Evidence of the Relationship between Concentration and Profitability ofBanking. Journal of Money, Credit and Banking, Vol. 17, p p.69-83.

[79] Stulz R. (2008). Risk Management Failures: What Are Theyand When Do They Happen? Journal of Applied Corporate Finance, Volume 20, Number 4, pp. 58-67.
[80] Suka J. N. (2010), The Impact of Capital Adequacy on The Financial Performance Of Commercial Banks Quoted At The NSE. MBA Unpublished Research Project, University of Nairobi.

[81] Talel L. (2010). A Survey of Risk Management Practices Adopted by Banking Institutions inKenya. MBA Unpublished Research Project, University of Nairobi.

[82] Tcankova L.(2002). Risk Identification; Basic Stage of Risk Management. Environmental Management and Health. Vol. 13 (3), pp. 290-297.

[83] Tobin, J. (1958). Liquidity Preference as Behavior towards Risk. Review of Economic Studies 25 (2): 65-86.

[84] Toutou J. (2011). The Relationship between Liquidity Risk and Performance, an EmpiricalStudy of Banks in Europe, 2005-2010; Umea School of Business.

[85] Weil J. (2012). The EU Smiled While Spain's Banks Cooked the Books. Bloomberg.

[86] Zeze O. S. (2012). The Relationship between Credit Risk Management Practices and Financial Performance of Commercial Banks in Liberia. MBA Unpublished Research Project, University of Nairobi. 